\begin{abstract}
2.
THE COLOR OF MONEY: THE EFFECTS OF FOREIGN DIRECT INVESTMENT ON ECONOMIC GROWTH IN TRANSITION ECONOMIES
\end{abstract}

\author{
by \\ Minsoon Lee \\ and \\ MoonJoong Tcha
}

DISCUSSION PAPER 02.16

DEPARTMENT OF ECONOMICS

THE UNIVERSITY OF WESTERN AUSTRALIA

35 STIRLING HIGHWAY

CRAWLEY, WA 6009

AUSTRALIA 


\title{
The Color of Money: The Effects of Foreign Direct Investment on Economic Growth in Transition Economies
}

\author{
Minsoo Lee* \\ Economics Department \\ Lincoln University \\ and \\ MoonJoong Tcha** \\ Department of Economics \\ University of Western Australia
}

\section{Introduction}

2. FDI and Economic Growth

3. Dynamic Equilibrium Path and FDI for Transition Economies

4. Estimation and Discussion

5. Conclusion

JEL Classification: O50, P39, F21

\footnotetext{
*Minsoo Lee: Economics Department, Lincoln University, Canterbury, New Zealand, Email: leem2@lincoln.ac.nz.**MoonJoong Tcha: Main correspondence, Department of Economics, The University of Western Australia, Crawley, WA, Australia, Email: mtcha@ecel.uwa.edu.au. We are grateful to Ken Clements for his constructive comments, Patricia Wang for research assistance and Andrew Semmens and Gina Yoon for editorial assistance. This project is financially supported by the ARC Small Grant and Departmental Research Grant, Department of Economics, UWA.
} 


\section{Introduction}

During the phase of transformation to a market economy, many countries of central and Eastern Europe, the Baltic States and the Commonwealth Independent States (CIS) initially experienced a severe decline in output. While these negative growth rates were larger than most economists had expected, some of the transition countries have now entered a stage of positive growth. This initial negative growth was sometimes understood as the reflection of the chaotic situation caused by the transition; however, in fact, this negative growth prevailed even before the transition. Figure 1 shows that the average GDP of Eastern European and Baltic countries had a downward trend from 1983 until 1991 followed by an upward trend thereafter. ${ }^{1}$ While this pertains to the average GDP growth of Eastern Europe and the Baltic countries, respective GDP for most countries except Hungary shows more or less the same pattern. This U-shaped curve attracted the attention of many economists and policy makers. For example, Blanchard (1996) points out that explaining the U-shaped pattern of output during this period is the major theoretical challenge facing economists working on transition economies. Figure 2 indicates that the average total investment of Eastern Europe and the Baltic countries behaves in a similar fashion as average GDP, which supports the conventional wisdom in economics, that there is a close relationship between investment and GDP.

Most countries of central and Eastern Europe, the Baltics and the CIS share similar economic characteristics. They are equipped with well-trained workforces, and thus possess relatively high quality human capital stock, considering the level of per

\footnotetext{
${ }^{1}$ This represents the unweighted average for eleven countries including Bulgaria, Croatia, the Czech Republic, Estonia, Hungary, Latvia, Lithuania, Poland, Romania, the Slovak Republic, and Slovenia.
} 
capita GDP (EBRD, 1997, p57). In contrast to human capital, the physical capital stock of these countries, in general, had been relatively obsolete since the mid 1980s and needed to be modernized through new investment (EBRD, 1995; Konai 1992, p197). The EBRD (1997) emphasizes that sustained growth requires investment in new plant and equipment and in new skills, as well as innovation in technology and business management. The major challenge facing the transition economies was how to escape the poverty trap by acquiring advanced technology and accumulating capital stock more effectively. Sachs (1996) claims that rapid as opposed to gradual systemic transformation helps these economies to remain on a growth path, where the radical transformation includes the institutional, legal, political, and administrative change of the economic system from state-ownership to the market allocation of resources. This argument is consistent with the conventional poverty trap argument of economic growth. Once the economy falls into the poverty trap, gradual or mild increases in capital stock only causes the economy to return to the low levels of the steady state (Barro and Sala-i-Martin, 1995). In fact, sustained efforts to achieve comprehensive reforms and economic stability are bearing fruit in some transition economies where the process of economic transformation is apparent.

This paper examines the role of foreign direct investment (FDI) in the growth of central and Eastern European countries, the Baltic States and the CIS around the transition period. The following section reviews the role of FDI, in particular, in transition economies. Section 3 constructs theoretical frameworks to analyze growth in the region and the role of FDI, and then develops a dynamic equilibrium path. The role of FDI is empirically estimated and presented in Section 4 . This section also discusses how 
total factor productivity (TFP), based on empirical findings, has improved throughout the transition period, and how these economies were able to escape falling victim to the poverty trap. Section 5 concludes this study.

\section{FDI and Economic Growth}

FDI is generally considered to play a critical role in improving total factor productivity, TFP, through the transfer of market-oriented technologies and business practices to the countries in transition, as well as by contributing to the accumulation of physical capital (for example, Urata and Kawai, 2000; Chan, 2000). Greater openness to investment provides a path for the international transfer of advanced production techniques and technical knowledge, thereby enabling transition countries to reduce the technology gap with industrial countries. Domestic investment (DI) in nationalized industries in the transition economies may contribute to the formation of capital; however, it may also lead to a lack of competition, surplus labor, inefficient management, and consequently, poor quality outputs.

While most of the capital investment carried out in these economies before the transition was DI, after the transition, the share of FDI as a percentage of total investment has been increasing. Figures 2 and 4, illustrate the two kinds of investment - average total investment (that is DI plus FDI) and FDI as a percentage of total investment - for these economies. The figures indicate that both total investment and FDI have grown consistently since 1991, which also coincide with the growth of GDP in these countries 
(as shown in Figure 1). ${ }^{2}$ Figures 3 and 4 support the view that a positive correlation between FDI and TFP should exist in the transition economies from 1991-2000. ${ }^{3}$ Figure 4 indicates that FDI in the economies started to increase soon after transition around 1992, and then increased dramatically from 1994, which coincided with a sharp increase of TFP as shown in Figure 3.

At the start of the transformation process to the market economy, many observers expected that substantial capital inflows would be one of the engines of economic development. However, in spite of strong incentives for foreign enterprises to invest in the transition countries owing to the existence of reasonably well-trained labor, the overall level of capital inflows remained low or modest, in most cases, during the initial phase (1991-1993) of the transition process, even after a rapid surge in $1991 .^{4}$ Froot (1994) points out that the number of investments and joint ventures with foreigners for all of eastern Europe rose extremely rapidly during the initial phase of transition; however, the average amount per investment remained small - about $\$ 150,000$. Foreign investors have been deterred by macroeconomic instability, uncertainties about the pace and commitment to structural reforms, and the lack of transparent and stable legal structures. ${ }^{5}$ Brunetti, Kisunko, and Weder (1997) also report that, differences in the degree of predictability of the institutional framework may be an important factor in explaining

\footnotetext{
${ }^{2}$ Due to the availability of data, the time span used for Figures 3 and 4 is different from that for Figures 1 and 2.

${ }^{3}$ The following sixteen countries were included in Figures 3 and 4: Albania, Belarus, Bulgaria, Croatia, the Czech Republic, Estonia, Hungary, Latvia, Lithuania, Moldova, Poland, Romania, the Russian Federation, the Slovak Republic, Slovenia and the Ukraine. Figure 4 is based on the data from the WIIW-WIFO Database (2001). Figure 3 will be explained in Section 4.

${ }^{4}$ The average annual FDI per worker in the 16 transition economies from 1991 to 1993 are $\$ 63, \$ 64$ and $\$ 94$, respectively.

${ }^{5}$ World Economic Outlook, 1995
} 
differences in FDI, as well as differences in economic growth across transitional economies.

An explosive increase of FDI inflowing to the region in 1995 is believed to have provided an important channel for the economies to achieve global integration and technology transfers. From the U-shaped pattern of GDP growth rates mentioned earlier, it is evident that since the 1990 's, some advanced transitory countries reached the upward portion of the U-curve, accompanied by substantial inflows of FDI.

The positive effects of FDI on growth have been established by many studies. However, it has been pointed out that the contribution of FDI to growth holds only when the host country has a minimum stock of human capital (for example, Borensztein, De Gregorio and Lee, 1998; Urata and Kawai, 2000) ${ }^{6}$. Most Eastern European and Baltic countries have relatively high quality human capital; and in this respect, these transition countries satisfy a necessary condition for them to benefit from FDI.

This paper analyzes the effects of FDI on growth in the transition economies of central and Eastern Europe, the Baltic States and the former USSR. Since time series data for each country after the transition are not long enough to analyze the dynamic impact of FDI on economic growth, cross-sectional and panel data (pertaining to the 16 transition countries outlined in footnote 4 during the ten-year period, 1991-2000) will be used to analyze the dynamic movement of equilibrium paths of those economies. After the theoretical exploration, phase diagrams for these economies will be generated from the results of empirical estimation, to confirm the dynamic movement of equilibrium paths for pre- and post- transition process.

\footnotetext{
${ }^{6}$ Eastern European and Baltic countries are not included in Borensztein et al (1998) and Urata and Kawai (2000).
} 


\section{Dynamic Equilibrium Path and FDI for Transition Economies}

This section formulates the growth model and analyzes the equilibrium path for capital stock with a low value of elasticity of substitution, which is appropriate for these economies. Consider an overlapping generations (OG) economy with two periods, similar to that in Samuelson's investigation (1958) of interest rates in pure exchange economies, and growth with national debt by Diamond (1965). In each period, the economy produces homogeneous goods by using two inputs, physical capital and efficiency units of labor. The goods can be used for consumption or saving. The supply of physical capital in each period is generated by the domestic aggregate savings from individual agents in the economy and foreign direct investment. Technological spillover into the country receiving FDI is allowed. Each agent is endowed with one unit of leisure when young, and then labor is supplied to the market inelastically.

Each agent maximizes his/hers intertemporal utility function in the form of a constant relative risk aversion (CRRA) utility function;

$$
\begin{gathered}
\operatorname{Max} U\left(c_{1 t}, c_{2 t}\right)=\frac{c_{1 t}^{\mathrm{l}-\gamma}-1}{1-\gamma}+\beta \frac{c_{2 t}^{1-\gamma}-1}{1-\gamma} \quad(\text { for } \gamma \neq 1)^{7} \\
\text { subject to } c_{1 t}=w_{t}-s_{t} \text { and } c_{2 t}=\left(1+r_{t+1}\right) s_{t},
\end{gathered}
$$

\footnotetext{
${ }^{7}$ As is well known, for $\gamma=1$, the intertemporal utility function becomes $U\left(c_{1 t}, c_{2 t}\right)=\ln c_{1 t}+\beta \ln c_{2 t}$.
} 
where $c_{t}$ is an individual's consumption at period $t, w_{t}, s_{t}$, and $r_{t}$ are wage incomes, savings, and interest rates at $t$ respectively, $\beta$ is the time discount factor, and $\frac{1}{\gamma}$ is the elasticity of substitution between consumption at two points of time, $t$ and $t+1 .^{8}$

A representative firm is producing outputs at $t$ by borrowing capital $(\mathrm{K})$ and hiring labor (L). The firm is supposed to have the CES (constant elasticity of substitution) production function:

$$
Y_{t}=F\left(K_{t}, L_{t}\right)=A_{t}\left[a K_{t}^{-\rho}+(1-a) L_{t}^{-\rho}\right]^{-1 / \rho},
$$

where $A_{t}$ is the efficiency parameter or total factor productivity $\left(A_{t}<0, \forall t\right), a$ is the distribution parameter $(0 \leq a \leq 1)$ and $\rho$ is the substitution parameter $(-1 \leq \rho<\infty)$.

The CES production function in equation (2) can be expressed in terms of per capita output and per capita capital stock:

$$
y_{t} \equiv \frac{Y_{t}}{L_{t}}=f\left(k_{t}\right)=A_{t}\left[a k_{t}^{-\rho}+(1-a)\right]^{-1 / \rho}
$$

where $y_{t}=\frac{Y_{t}}{L_{t}}$ and $k_{t}=\frac{K_{t}}{L_{t}}$ are the output and capital input per worker, respectively.

The elasticity (technical rate) of substitution between two factors $(\sigma)$ is:

\footnotetext{
${ }^{8}$ As is well known, $\gamma$ is the coefficient of relative risk aversion.
} 
$\sigma=\frac{1}{1+\rho} \geq 0 .{ }^{9}$ As is well known, when $\sigma=1$ (or $\rho=0$ ) the firm has a Cobb-Douglas production function in the form of $f\left(k_{t}\right)=A_{t} k_{t}^{a}$, and when $\sigma \rightarrow 0$ (or $\rho=\infty$ ) the firm has a Leontief production function in the form of $f\left(k_{t}\right)=A_{t} \min \left\{k_{t}, \lambda\right\}$. For small $\sigma \in(0,1)$, i.e., when $0<\rho<\infty$, the intensive CES production function is in the form of,

$$
f\left(k_{t}\right)=A_{t} \ln \left(1+k_{t}\right)
$$

where per worker output depends on $A_{l}$, total factor productivity, which in turn depends on such factors as internal technological progress, technological spillover, human capital, etc., and capital-labor ratio. ${ }^{10}$

With equation (4) in mind, Figures 2 and 3 indicating the declining growth rate of Eastern European and Baltic countries from 1983 to 1991, may be explained by declining investment, and the rapid positive growth from 1994 by an increase in investment and improvement of TFP. Moreover, the marginal product of capital is diminishing faster with lower elasticity of substitution. An explanation on the low elasticity of substitution between capital and labor for centrally planned economies goes back to Weitzman (1970). He argues that, aside from a geometric time trend, the postwar Soviet growth record is adequately accounted for by a CES production function with elasticity of substitution significantly less than one. Easterly and Fischer (1995) also claim that the Soviet's extensive growth (rising capital-to-output ratios) was no greater than that of

\footnotetext{
${ }^{9}$ The elasticity of substitution $(\sigma)$ between $\mathrm{K}$ and $\mathrm{L}$ can be defined as $\Delta(\mathrm{K} / \mathrm{L}) / \mathrm{K} / \mathrm{L} / \Delta\left(\mathrm{MP}_{\mathrm{L}} / \mathrm{MP}_{\mathrm{K}}\right) / \mathrm{MP}_{\mathrm{L}} / \mathrm{MP}_{\mathrm{K}}$. ${ }^{10}$ See Azariadis (1993).
} 
market economies, such as Japan and Korea, but a low elasticity of substitution between capital and labor implied especially acute diminishing returns to capital in comparison with market economies. Our empirical estimates on the elasticity of substitution verify that it is significantly less than unity for those transition economies, ${ }^{11}$ which supports the use of the production function as (4).

The intensive CES function $f$ in (4) is twice continuously differentiable, increasing, concave, and $f(0)=0$. In addition, the two first derivatives satisfy Inada conditions: $\lim _{k_{t} \rightarrow 0} f^{\prime}\left(k_{t}\right)=\frac{A_{t}}{\left(1+k_{t}\right)}=A_{t}$, and $\lim _{k_{t} \rightarrow \infty} f^{\prime}\left(k_{t}\right)=\frac{A_{t}}{\left(1+k_{t}\right)}=0$. Accordingly, this production function (4) satisfies the neoclassical conditions that assure the existence of an interior solution to the producers' profit-maximization problem.

The interest rate and wage income of the representative consumer (worker) in this economy can be determined in terms of the intensive production function:

$$
\begin{aligned}
& 1+r_{t} \equiv R_{t}=f^{\prime}\left(k_{t}\right)+1-\delta, \text { and } \\
& w_{t}=f\left(k_{t}\right)-k_{t} f^{\prime}\left(k_{t}\right),
\end{aligned}
$$

where $\delta$ is a depreciation rate.

Dynamic equilibrium in this economy satisfies the condition that capital per worker at $t+1$ is equal to the saving by workers with wage income $w_{t}$, capital transferred from period $t$ and per capita net FDI, $z_{t+l:}{ }^{12}$

\footnotetext{
${ }^{11}$ Section 4 presents and discusses the empirical findings.

${ }^{12} z_{t}>0$ for all countries in this case, since they are capital importing countries. We assume that $z_{t}$ is exogenous to $k_{i}$.
} 
(6) $(1+n) k_{t+1}=s\left(R_{t}, w\left(k_{t}\right)\right)+k_{t}(1-\delta)+z_{t+1}$,

where $s\left(R_{t}, w\left(k_{t}\right)\right)$ is the saving function that maximizes (1), and $n$ is the population growth rate. We suppose that $s$ is an increasing function of $R$ and $w$, where $s(1, w)=0$ $\forall w \geq 0, s(R, 0)=0 \forall R \geq 0$, and $[\partial \mathrm{s}(\mathrm{R}, \mathrm{w}) / \partial \mathrm{w}] \in(0,1)$.

From the first order condition to maximize (1) using (5a) and (5b), the savings function should satisfy:

$$
s_{t}=\Phi_{t} w_{t}, \quad \text { where } \Phi_{t}=\frac{1}{1+(1+\rho)^{1 / \gamma} R_{t}^{(\gamma-1) / \gamma}}
$$

Therefore, the equilibrium path of capital stock, (6), can be written as:

(7) $k_{t+1}=\frac{A_{t} \Phi_{t}}{(1+n)}\left(\ln \left(1+k_{t}\right)-\frac{k_{t}}{1+k_{t}}\right)+\frac{z_{t+1}}{(1+n)}$,

where $A_{t}$ is a function of $z_{j} \forall j=1,2, \ldots, t$, and $\left(\partial A_{t} / \partial z_{j}\right)>0$, as was found by other studies, in particular, in the presence of human capital. Equation (7) clearly shows the two channels through which FDI contributes to capital formation and economic growth. First, it has a direct effect on $k_{t+l}$, of which the partial effect is $(1 / 1+n)$. Second, it affects $A_{t}$, which in turn affects $k_{t+l}$. 
The family of phase diagrams of equation (7) is shown in Figure 5. Three different cases of phase diagrams are presented, depending on the size of total factor productivity, $A_{t}$, relative to a critical value of total factor productivity, $\mathrm{A}^{*}$.

Case I. For a relatively large $A_{t}>A^{*}$, the economy follows the dynamic equilibrium path labeled 'Large' in Figure 5. An economy with this equilibrium path will have multiple equilibria; two stable and one unstable steady states. As indicated in Figure 5, $k$ $=k_{2}$ and $k=k_{5}$ are stable steady states, and $k=k_{3}$ is unstable. An economy with its capital stock exceeding $k_{3}$ will converge to $k_{5}$ and any economy with capital stock below $k_{3}$ will fall into the development poverty trap converging to $k_{2}$.

Case II. For a critical value of $A_{t}=A^{*}$, the economy stays on the dynamic equilibrium path labeled 'Bifurcation' in Figure 5..$^{13}$ Azariadis and Drazen (1990) explain the threshold effects as radical differences in dynamic behavior arising from local variations in the social returns to scale. They argue that such bifurcation might result from the technical features of the accumulation process in an economy with both physical and human capital. In this case $k=k_{1}$ is the stable steady state. The value $k=k_{4}$ is stable from above and unstable from below. This implies that even though the economy has a large capital stock, $k>k_{4}$, it will eventually converge to $k=k_{l}$.

Case III. For relatively small values of $A_{t}<A^{*}$, the economy follows the dynamic equilibrium path labeled 'Small' in Figure 5. If the economy follows this equilibrium

\footnotetext{
${ }^{13}$ For a fuller description of bifurcation theory, see Devaney (1989).
} 
path, then $k=k_{0}$ is the only stable steady state. An economy with any level of capital stock in this case will eventually converge to the undesirable stable steady state, $k=k_{0}$.

Equation (7) and these three cases of equilibrium paths indicate, that the growth of a country in the presence of low elasticity of substitution between factors depends heavily on the size of capital investment $\left(k_{t}\right.$ and $\left.z_{t}\right)$ and technology, represented by $A_{t}$ in this study. The following section will estimate the relevant parameters and generate the short-run dynamic movements of phase diagrams for transition economies.

\section{Estimation ${ }^{14}$ and Discussion}

\section{Estimation of Elasticity of Substitution}

The theoretical exploration of the equilibrium path for growth carried out in the previous section, was based on intensive production function (4), which, in turn, was derived from the assumption that the elasticity of substitution between factors is less than one. Therefore, it is crucial to confirm whether these economies around the time of transition did in fact possess low elasticity. The elasticity of substitution between two factors in these economies was estimated using a generalized CES production function: $Y_{t}=F\left(K_{t}, L_{t}\right)=A\left[a K_{t}^{-p}+(1-a) L_{t}^{-\rho}\right]^{-1 / p}$. Nonlinear least squares estimation using Gauss-Newton's method (Greene, 2000), was carried out based on the pooled data for

\footnotetext{
${ }^{14}$ Most data sets for this paper come from World Development Indicators (various years). FDI data are from the WIIW-WIFO DATABASE (various years).
} 
sixteen countries in the region for ten years $(1991-2000)^{15}$. Table 1 summarizes the results. As $\rho$ is estimated as 1.0216 , the elasticity of substitution $\sigma$ is computed as 0.4946 , which justifies the use of equation (4) as an intensive CES production function. This type of production function captures the properties of rapid dynamic economic movements for transition economies. In fact, the elasticity of substitution of centrally planned economies for the previous periods was found to be even lower than the figure estimated in this study. For example, Weitzman (1970) estimates the elasticity of substitution for the Soviet Union during the period $1950-66$ by using the method of minimizing the sum of squared logarithmic residuals, and finds the elasticity of substitution to be $0.274 .^{16}$

\section{DI and FDI - The Color of Money}

As low levels of elasticity were found, the effects of DI and FDI on economic growth are estimated based on the intensive production function in equation (4). The production function (4) is approximated using Taylor series expansion up to the second order by separating $k_{t}^{D I}$ and $k_{t}^{F D I}$, where $k_{t}^{D I}$ and $k_{t}^{F D I}$ are capital per worker accumulated by DI and FDI respectively. The equation estimated was, therefore,

\footnotetext{
${ }^{15}$ It would be more desirable to have data for these economies before the transition period; however, the quality and reliability of data for these economies before 1990 are too poor to be incorporated in this study. 16 The low level of elasticity of substitution for the centrally planned economies seems quite robust. We estimated the elasticity of substitution from the same data as Weitzman used, by using the same nonlinear regression technique that we used in this study, and found that the elasticity was about 0.24 . We also estimated the elasticity of substitution for Soviet industry using the data from Easterly and Fischer (1995), and the elasticity turned out to be about 0.13 .
} 
(8)

$$
f\left(k_{i t}\right)=A_{0}+A_{1} k_{i t}^{F D I}+A_{2} k_{i t}^{D I}+A_{3}\left(k_{i t}^{F D I}\right)^{2}+A_{4}\left(k_{i t}^{D I}\right)^{2}+A_{5} k_{i t}^{F D I} * k_{i t}^{D I}+u_{i t}^{17}
$$

$$
\text { where } i=1,2, \cdots, N \text { and } t=1,2, \cdots, T \text {. }
$$

All the units are in \$thousands, and a depreciation rate of $6 \%$ is uniformly applied to all economies.

Suspecting that the error term has a first-order autoregressive error structure, $u_{i t}=\rho_{i} u_{i, l-1}+\varepsilon_{i t}$, we allow the contemporaneous correlation between cross sections $E\left(u_{i t} u_{j t}\right)=\sigma_{i j}^{2}$ and heteroscedasticity $E\left(u_{i t}^{2}\right)=\sigma_{i t}^{2}$ (Parks, 1967). We also impose the following assumptions for the error disturbance term: $E\left(\varepsilon_{i t}\right)=0, E\left(u_{i, t-1} \varepsilon_{j t}\right)=0$, $E\left(\varepsilon_{i t} \varepsilon_{j t}\right)=\phi_{i j}, E\left(\varepsilon_{i t} \varepsilon_{j s}\right)=0($ for $s \neq t)$, and $E\left(u_{i t} u_{j t}\right)=\sigma_{i j}^{2}=\phi_{i j} /\left(1-\rho_{i} \rho_{J}\right)$

With these assumptions on the error structure and components, the covariance matrix for the vector of random errors $\underline{u}$ can be expressed as

$$
\begin{gathered}
E\left({\underline{u u^{\prime}}}^{\prime}\right)=V=\left[\begin{array}{cccc}
\sigma_{l 1}^{2} \underline{\Omega}_{11} & \sigma_{l 2}^{2} \underline{\Omega}_{12} & \cdots & \sigma_{I N}^{2} \underline{\Omega}_{I N} \\
\sigma_{2 l}^{2} \underline{\Omega}_{2 l} & \sigma_{22}^{2} \underline{\Omega}_{22} & \cdots & \sigma_{2 N}^{2} \underline{\Omega}_{2 N} \\
\vdots & \vdots & \ddots & \vdots \\
\sigma_{N l}^{2} \underline{\Omega}_{N 1} & \sigma_{N 2}^{2} \underline{\Omega}_{N 2} & \cdots & \sigma_{N N}^{2} \underline{\Omega}_{N N}
\end{array}\right], \\
\text { where } \underline{\Omega}_{l j}=\left[\begin{array}{cccc}
1 & \rho_{j} & \cdots & \rho_{j}^{T-1} \\
\rho_{i} & 1 & \cdots & \rho_{j}^{T-2} \\
\vdots & \vdots & \ddots & \vdots \\
\rho_{i}^{T-1} & \rho_{i}^{T-2} & \cdots & 1
\end{array}\right] .
\end{gathered}
$$

\footnotetext{
${ }^{17}$ While we fully acknowledge the importance of human capital, due to limitations surrounding the
} 
The matrix $V$ is estimated by a two-stage procedure, and the parameters in equation (8) are then estimated using the general linear squared (GLS) method.

A consistent estimator of the first-order autoregressive parameter is obtained as follows: $\quad \hat{\rho}_{i}=\left(\sum_{i=2}^{T} \hat{u}_{i t} \hat{u}_{i, t-1}\right) /\left(\sum_{t=2}^{T} \hat{u}_{i, t-1}^{2}\right) \quad i=1,2, \cdots, N$. Most of estimated first-order autoregressive parameters are found to be very close to the unity indicating that equation (8) would be spurious. To overcome the spurious regression problem due to the large first order autoregressive parameters, we estimate the growth equation (8) using the first difference series;

(9) $\Delta f\left(k_{i t}\right)=A_{0}+A_{1} \Delta k_{i t}^{F D I}+A_{2} \Delta k_{i t}^{D I}+A_{3} \Delta\left(k_{i t}^{F D I}\right)^{2}+A_{4} \Delta\left(k_{i t}^{D I}\right)^{2}+A_{5} \Delta\left(k_{i t}^{F D I} * k_{i t}^{D I}\right)+u_{i t}$, where $i=1,2, \cdots, N$ and $t=1,2, \cdots, T$.

By taking the first difference, equation (9) illustrates relationship between the growth of output per worker and various types of investment variables.

The results are reported in column (1) Table $2 .^{18}$ Every coefficient in the model is significant, at least at the 1 per cent level, except the interactive term. The negative constant term $A_{0}$ indicates that the change in per capita GDP in for the economies would be negative (i.e., they would record negative growth) if there is no change in DI and FDI. While the coefficients for both FDI and DI are significant and positive, that for FDI is more than four times larger than that for DI. While a $\$ 1000$ increase in capital per resolved as more data are accumulated. 
worker in the form of DI produces about $\$ 500$ of marginal product per worker, ceteris paribus, the same increase in the form of FDI produces about $\$ 2300$ of marginal product per worker. It is noteworthy that for these economies, the marginal increase in the value of output per worker falls short of the marginal increase in domestic investment per worker. The coefficients for the squared term on DI and FDI are negative; the effects of DI and FDI on economic growth are diminishing. While the magnitudes of the two coefficients for quadratic terms are small, $A_{3}$ turns out to be larger than $A_{4}$. It implies that, in the long run, when capital per worker in the economy reaches a certain level, diminishing marginal return would take place for FDI earlier and to a larger extent than DI. This finding needs further investigation. The effect of the interactive term of FDI and $\mathrm{DI}$ on economic growth is insignificant, which implies that there is no statistical evidence that FDI has either a crowding-out effect on or a positive interaction with DI for these economies during the transitional period. This finding is consistent with Borensztein et al (1998).

Based on these results ${ }^{19}$, equation (9) reduces to the following form for parsimony and is estimated by:

$$
\begin{gathered}
\Delta f\left(k_{i t}\right)=A_{0}+A_{1} \Delta k_{i t}^{F D I}+A_{2} \Delta k_{i t}^{D I}+A_{3} \Delta\left(k_{i t}^{F D I}\right)^{2}+A_{4} \Delta\left(k_{i t}^{D I}\right)^{2}+u_{i t}, \\
\text { where } i=1,2, \cdots, N \text { and } t=1,2, \cdots, T .
\end{gathered}
$$

\footnotetext{
${ }^{18}$ As most economies demonstrated similar patterns of FDI inflow and GDP increases and our major concern is not an individual country's specific performance, country characteristics are not taken into account in this study.

${ }^{19} \mathrm{~F}$-value is 0.12 and $\mathrm{P}$-value is 0.7246 .
} 
The results are reported in column (2) in Table 2. Every coefficient in the model is significant at the 1 per cent level, and no significant change in the magnitude of coefficients is found. These findings robustly confirm that foreign direct investment plays a crucial role in the economic development of the transition economies. A significant and negative constant catches the time effect and implies that if neither domestic nor foreign direct investment per capita does not increase over time, per capita product will decrease over time by approximately $\$ 71$ each year.

For the reasons why, and in what ways, foreign direct investment is more productive than domestic investment, the conventional argument regarding the positive effects of foreign direct investment probably can be applied; in regards to the improvement in the quality of capital stock as well as the accumulation of capital. Foreign direct investment can help an economy to be more competitive, productive, and efficient as demonstrated in studies using other countries. Moreover, foreign direct investment can bring economic spillovers to the host country, such as transfers of managerial and technological expertise. Therefore, it is one of our major concerns to examine whether the TFP of these economies improved together with the inflow of FDI. More empirical analyses of this issue follow.

\section{Estimating Total Factor Productivity}

Equation (7) explains how an economy's growth can be affected by determinants such as capital intensity and total factor productivity. This subsection investigates why many transition economies were able to achieve higher rates of economic growth after transition than during the pre-transition period, by estimating total factor productivity 
using equation (4) and then applying equation (7). Data for the transition economies comprises the sixteen countries as listed in section 1 .

The total factor productivities of the transition economies are estimated for each year from 1991 to 2000, using equation (4), and the results are summarized in Table 3. Table 3 also reports how the FDI share of investment increased for the same period. The total factor productivity is seen to increase around 1995, and relatively high levels of TFP have been maintained throughout the second half of the decade. In order to apply this finding further to growth in the region, the entire period examined in this study is demarcated into two stages according to the stage of transition: ${ }^{20}$ the early post-transition period (1990-1995) and the late post-transition period (1995-2000). Figure 6 depicts the empirically generated phase diagrams for each of the pre- and post-transition periods, where those for the two post-transition periods are reconstructed based on information in Table 3 and equation (7). The phase diagrams for the two pre-transition periods were based on our preliminary findings and their growth performance.

The phase diagrams for the pre-transition periods stay below the forty-five degree line resembling the theoretical one with small $A_{t}$ labeled as 'Small' in Figure 5; however, the phase diagrams for the post-transition periods surpass the threshold value and cut the forty-five degree line from above. The arrow lines in the figure illustrate how the equilibrium capital stock moved over time. Suppose an economy's initial level of per capita capital (regardless of whether it is foreign or domestic capital) is $k_{A}$. The phase

\footnotetext{
${ }^{20}$ Initially we divided the entire period into four, such as early pre-transition period (1980-1985), late pretransition period (1986-1989), early post-transition period (1990-1995) and late post-transition period (1995-2000). However, as discussed previously, only a few countries' data were available for the period prior to 1991, and even when they were available, their quality was not reliable. While the results are still consistent with this study's argument, they are not reported. More detailed information is available from the authors.
} 
diagram explains that capital intensity in the next period will be $a$, and then move to $b$. If the late pre-transition period curve shifts upwards due to further capital accumulation and an increase in total factor productivity, the next period's level of capital will be $c$, instead of $c^{\prime}$. However, this level of capital intensity and total factor productivity is not sufficient to save this economy from the poverty trap. As discussed previously, the rapid inflow of FDI would contribute to this shift through capital accumulation and technology transfers, and help the economy escape the poverty trap. Once the economy's phase line shifts up to 'the early post-transition', the next period's capital intensity moves from $d$ to $e$, and then to $f$. A continuous inflow of FDI and an increase in factor productivity shifts the line even higher (to 'the late-transition'), implying that the economy is able to accumulate more capital and utilize better technology.

The transition economies might fall into the case of bifurcation or 'Small' (Cases II and III in Section 3) until the time that they moved toward market economies (19891991). Huge inflows of FDI since early the 1990s (Figure 4 and Table 3), accompanied by a rapid increase in total factor productivity (Figure 3 and Table 3), helped them to surpass the threshold. Therefore, their investment and GDP started to increase and they were able to escape the poverty trap and move onto a growth path.

\section{Conclusion}

While it is frequently pointed out that many transition economies experienced a dramatic decline in output during the initial phase of transformation to a competitive market structure, this was, in fact, a chronic problem for these economies even before the 
transition, accompanied by a decline in investment and (possibly) stagnated total factor productivity. Economies with low elasticity of substitution between capital and labor and low total factor productivity, have been destined to suffer from rapidly diminishing rates of marginal productivity. To attract foreign direct investment, which can transfer sophisticated technology and introduce management innovations from advanced economies together with capital, would be one of the most effective ways for these economies to improve their total factor productivity and, in doing so, eventually avoid the poverty trap. Huge inflows of foreign direct investment will change the composition of investment and improve the quality of capital stock, as well as increasing the absolute amount of total capital. The crowding-out effect of DI by FDI is not confirmed in this study.

This study also explores the dynamic growth path for the transition economies, focusing on the role of FDI. Based on the findings that the elasticity of substitution is low in these economies, we show how the economies could fall into the poverty trap, and how FDI helped them escape from it. Empirical findings also confirm that FDI contributed more to the growth of these economies than DI did. The availability of reliable data for these economies before the transition period would enhance further research on these issues. 


\section{References}

Azariadis, C. (1993). Intertemporal Macroeconomics, Blackwell Publishers: Cambridge, MA, USA.

Azariadis, C. and A. Drazen (1990). "Threshold Externalities in Economic Development." Quarterly Journal of Economics, 105 (2), 501-526.

Barro, R.J. and X. Sala-i-Martin (1995). Economic Growth, McGraw Hill: New York.

Beattie, B. and C. Taylor (1985). The Economics of Production, John Wiley \& Sons, Inc: New York.

Blanchard, O. (1996). "Assessment of The Economic Transition in Central and Eastern Europe: Theoretical Aspects of Transition." American Economic Review, 86 (2), 117-122.

Borensztein, E., J. De Gregorio and J. Lee (1998). "How Does Foreign Direct Investment Affect Economic Growth?" Journal of International Economics, 45, 115-35.

Brunetti, A., G. Kisunko and B. Weder (1997). "Institutions in Transition: Reliability of Rules and Economic Performance in Former Socialist Countries", World Bank Policy Research Working Paper No. 1809 , Washington DC: The World Bank.

Chan, V. (2000). "Foreign Direct Investment and Economic Growth in Taiwan's Manufacturing Industries." In Ito, T. and A. Krueger eds. The Role of Foreign Direct Investment in East Asian Economic Development, 349-66. The University of Chicago Press: Chicago.

Devaney, R. (1989). An Introduction to Chaotic Dynamic Systems, Addison-Wesley Publishing Company: Boston.

Diamond, P. (1965). "National Debt in a Neoclassical Growth Model." American Economic Review, 55, 1026-50.

Easterly, W. and S. Fischer (1995). "The Soviet Economic Decline." The World Bank Economic Review, 9 (3), 341-371.

Edwards, S. (1993). "Openness, Trade Liberalization, and Growth in Developing Countries." Journal of Economic Literature, 31 (3), 1358-1393. 
European Bank for Reconstruction and Development (EBRD) (1995, 1996, 1997). Transition Report 1995: Investment and Enterprise Development, European Bank for Reconstruction and Development: London.

Froot, K. (1994). "Foreign Direct Investment in Eastern Europe: Some Economic Considerations." in Blanchard, O.J., K.A. Froot, and J.D. Sachs eds. The Transition in Eastern Europe Vol.2, 293-316, University of Chicago Press: Chicago.

Greene, W. (2000). Econometric Analysis, $4^{\text {th }}$ edition, Prentice Hall International, Inc.: New Jersey.

International Monetary Fund (various years). World Economy Outlook, International Monetary Fund: Washington D.C.

Konai, J. (1992). The Socialist System, Oxford University Press: Oxford.

Lansbury, M., N. Pain and K. Smidkova (1996). "Foreign Direct Investment in Central Europe Since 1990: An Econometric Study." National Institute Economic Review, 156, 104-124.

Parks, R. (1967). "Efficient Estimation of a System of Regression Equations When Disturbances Are Both Serially Contemporaneously Correlated." Journal of the American Statistical Association, 62, 500-509.

Samuelson, P. (1958). "An Exact Consumption-loan Model of Interest with or without the Social Contrivance of Money." Journal of Political Economy, 66, 467-82.

Sachs, J. (1996). "The Transition at Mid Decade." AEA Papers and Proceedings, 86 (2), 128-133.

Urata, S. and H. Kawai (2000). "Intrafirm Technology Transfers by Japanese Manufacturing Firms in Asia." in Ito, T. and A. Krueger eds. The Role of Foreign Direct Investment in East Asian Economic Development, 49-78, The University of Chicago Press: Chicago.

Weitzman, M. (1970). "Soviet Postwar Economic Growth and Capital-Labor Substitution." American Economic Review, 60(5), 676-692.

WIIW-WIFO (various years). WIIW-WIFO Database. Vienna. The Viennese Institute for International Economic Studies. 
World Bank (various years). World Development Outlook. Washington D.C. The World Bank. 
Table 1. Estimation of the CES Production Function ${ }^{\text {(a) }}$

(Non-Linear Least Squares Estimation using the Panel Data for 1991-2000) ${ }^{(\mathrm{b})}$

\begin{tabular}{ccccc}
\hline \multirow{2}{*}{ Parameter } & Estimate & $\begin{array}{c}\text { Asymptotic } \\
\text { Standard Error }\end{array}$ & \multicolumn{2}{c}{$\begin{array}{c}\text { Asymptotic 95\% } \\
\text { Confidence Limit }\end{array}$} \\
\cline { 4 - 5 } & & & Lower & Upper \\
\hline $\log (\mathrm{A})$ & $-0.3756^{* *}$ & 0.1254 & -0.6775 & -0.0743 \\
$\mathrm{~A}$ & $0.2548^{*}$ & 0.1419 & -0.0261 & 0.5356 \\
$\rho$ & $1.0216^{*}$ & 0.5244 & -0.0163 & 2.0595 \\
\hline
\end{tabular}

Method: Gauss-Newton

F-Value: 53.20, P-value: $<.0001$

The elasticity of substituion, $\sigma=1 /(1+\rho)=0.4946$

(a) Equation estimated : $\log (Y)=\log (A)+(-1 / \rho) \log \left[a K_{t}^{-p}+(1-a) L_{t}^{-\rho}\right]$

(b) Countries: Albania, Belarus, Bulgaria, Croatia, the Czech Republic, Estonia, Hungary, Latvia, Lithuania, Moldova, Poland, Romania, the Slovak Republic, Slovenia, Russia, and the Ukraine.

Note: ${ }^{* *}$ and $*$ mean to be significant at the $5 \%$ and $10 \%$ levels, respectively. 
Table 2. The Effects of DI and FDI on Growth

(Generalized Least Squares Estimation using Panel Data)

\begin{tabular}{|c|c|c|}
\hline Parameters & (1) & $(2)$ \\
\hline$A_{0}$ & $\begin{array}{c}-0.059^{* * * *} \\
(0.009)\end{array}$ & $\begin{array}{c}-0.071^{* * *} \\
(0.007)\end{array}$ \\
\hline $\mathrm{A}_{1}$ & $\begin{array}{c}2.308 * * * \\
(0.349)\end{array}$ & $\begin{array}{c}2.393^{* * *} * \\
(0.118)\end{array}$ \\
\hline$A_{2}$ & $\begin{array}{c}0.540^{* * * *} \\
(0.038)\end{array}$ & $\begin{array}{c}0.526^{* * * *} * \\
(0.036)\end{array}$ \\
\hline $\mathrm{A}_{3}$ & $\begin{array}{c}-1.089 \text { ***** } \\
(0.061)\end{array}$ & $\begin{array}{c}-1.056 * * * \\
(0.042)\end{array}$ \\
\hline $\mathrm{A}_{4}$ & $\begin{array}{c}-0.007 * * * * \\
(0.002)\end{array}$ & $\begin{array}{c}-0.007 * * * \\
(0.002)\end{array}$ \\
\hline$A_{5}$ & $\begin{array}{c}0.011 \\
(0.030)\end{array}$ & - \\
\hline R-Square & 0.9535 & 0.9343 \\
\hline Mean Square Errors & 0.5360 & 0.5505 \\
\hline Degrees of Freedom & 138 & 139 \\
\hline Countries & $\hat{\rho}$ & $\hat{\rho}$ \\
\hline Albania & 0.257 & 0.266 \\
\hline Belarus & 0.781 & 0.780 \\
\hline Bulgaria & -0.418 & -0.412 \\
\hline Croatia & 0.387 & 0.382 \\
\hline Czech Rep. & 0.223 & 0.227 \\
\hline Estonia & 0.093 & 0.095 \\
\hline Hungary & -0.314 & -0.277 \\
\hline Latvia & 0.145 & 0.144 \\
\hline Lithuania & 0.432 & 0.431 \\
\hline Moldova & -0.607 & -0.608 \\
\hline Poland & 0.274 & 0.274 \\
\hline Romania & 0.014 & 0.029 \\
\hline Slovak Rep. & 0.638 & 0.639 \\
\hline Slovenia & 0.165 & 0.164 \\
\hline Russia & 0.155 & 0.156 \\
\hline Ukraine & -0.394 & -0.396 \\
\hline
\end{tabular}

Note: The numbers in parenthesis are the standard error. *** stands for $1 \%$ significant level. 
Table 3. Estimation of Total Factor Productivity $A_{t}, 1991-2000$

(Non-linear Least Squares Estimation Using Cross-section data) ${ }^{(a)}$

\begin{tabular}{ccccccc}
\hline Year & TFP $^{(b)}$ & $\begin{array}{c}\text { Standard } \\
\text { Error }\end{array}$ & F-value & P-value $>\mathrm{F}$ & $\mathrm{R}^{2}$ & $\begin{array}{c}\text { FDI as \% of } \\
\text { Total Investment }\end{array}$ \\
\hline 1991 & 1.230 & 0.100 & 150.90 & $<.0001$ & .9096 & 0.85 \\
1992 & 1.078 & 0.105 & 105.82 & $<.0001$ & .8758 & 1.51 \\
1993 & 1.022 & 0.118 & 74.76 & $<.0001$ & .8329 & 3.44 \\
1994 & 1.078 & 0.148 & 53.36 & $<.0001$ & .7806 & 3.29 \\
1995 & 1.270 & 0.199 & 40.62 & $<.0001$ & .7303 & 7.24 \\
1996 & 1.312 & 0.205 & 40.89 & $<.0001$ & .7316 & 6.19 \\
1997 & 1.338 & 0.182 & 53.90 & $<.0001$ & .7823 & 8.02 \\
1998 & 1.405 & 0.198 & 50.15 & $<.0001$ & .7698 & 11.75 \\
1999 & 1.381 & 0.200 & 47.27 & $<.0001$ & .7591 & 14.84 \\
2000 & 1.357 & 0.169 & 64.53 & $<.0001$ & .8114 & 13.80 \\
\hline
\end{tabular}

NOTE:(a) 16 countries as mentioned in Table 1 are used for each year.

(b) All estimates are significant at the $1 \%$ level. 
Figure 1

Average GDP of Eastern European and the Baltic countries

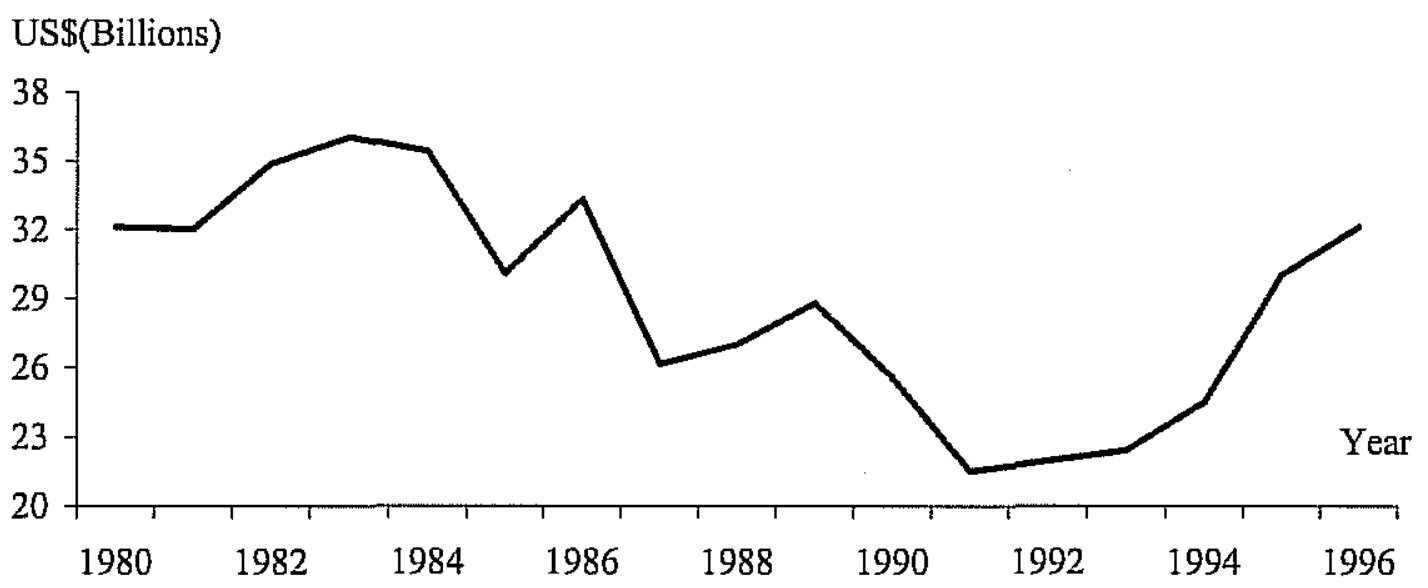

Figure 2

Average Total Investment of Eastern European and the Baltic Countries

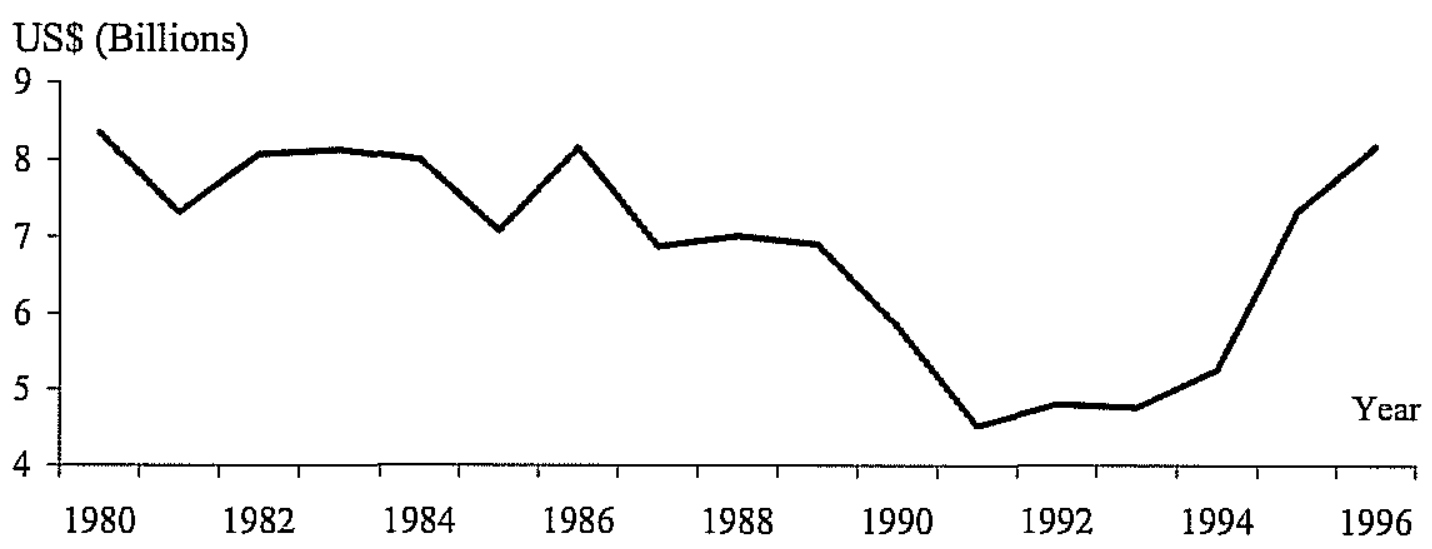


Figure 3

Total Factor Productivity of Eastern European and the Baltic Countries

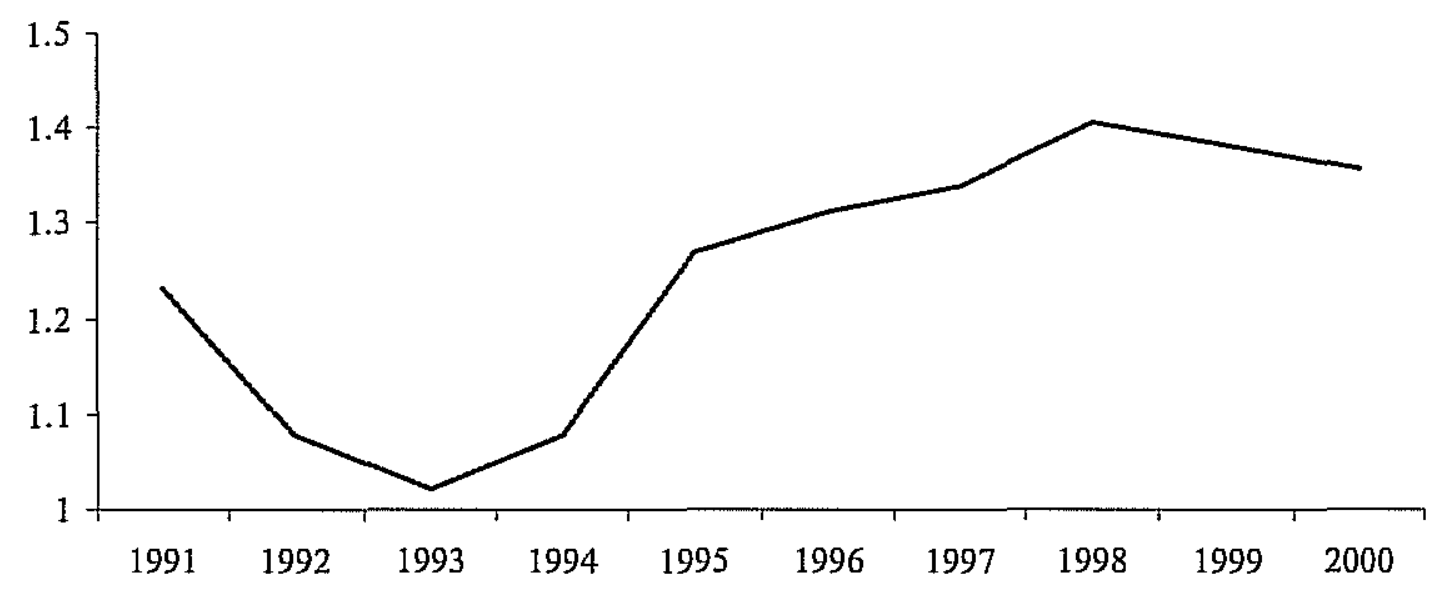

Figure 4

FDI of Eastern European and the Baltic Countries

(as a \% of Total Investment)

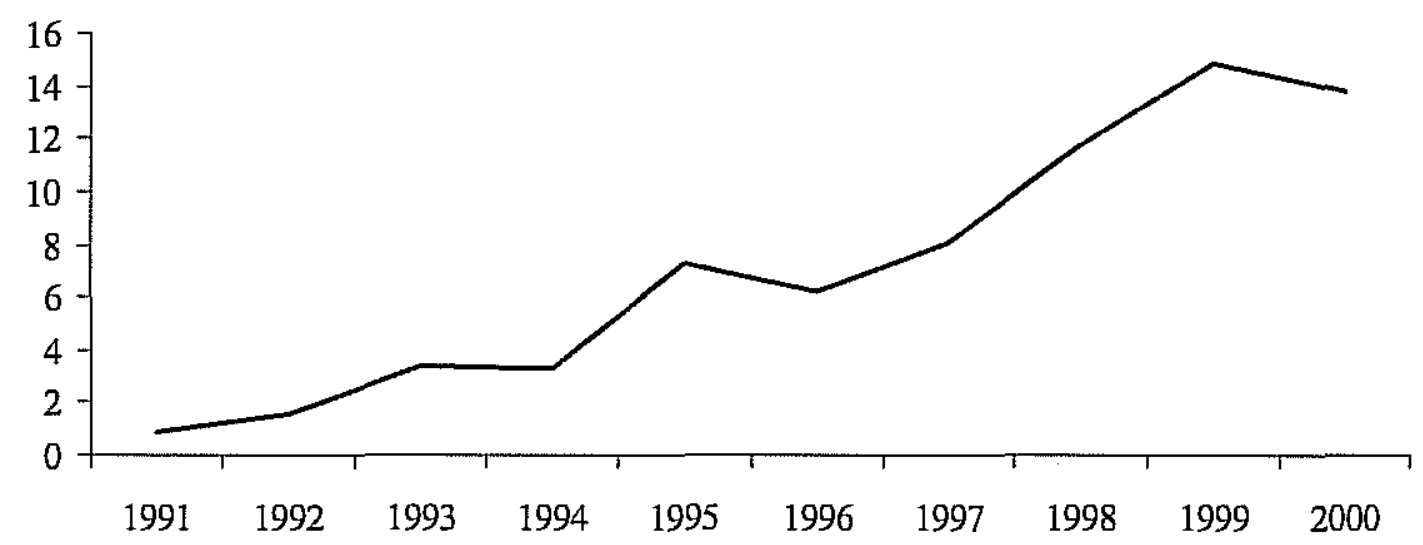


Figure 5

Phase Diagram for Three Paths

(for $0<\sigma<1$ )

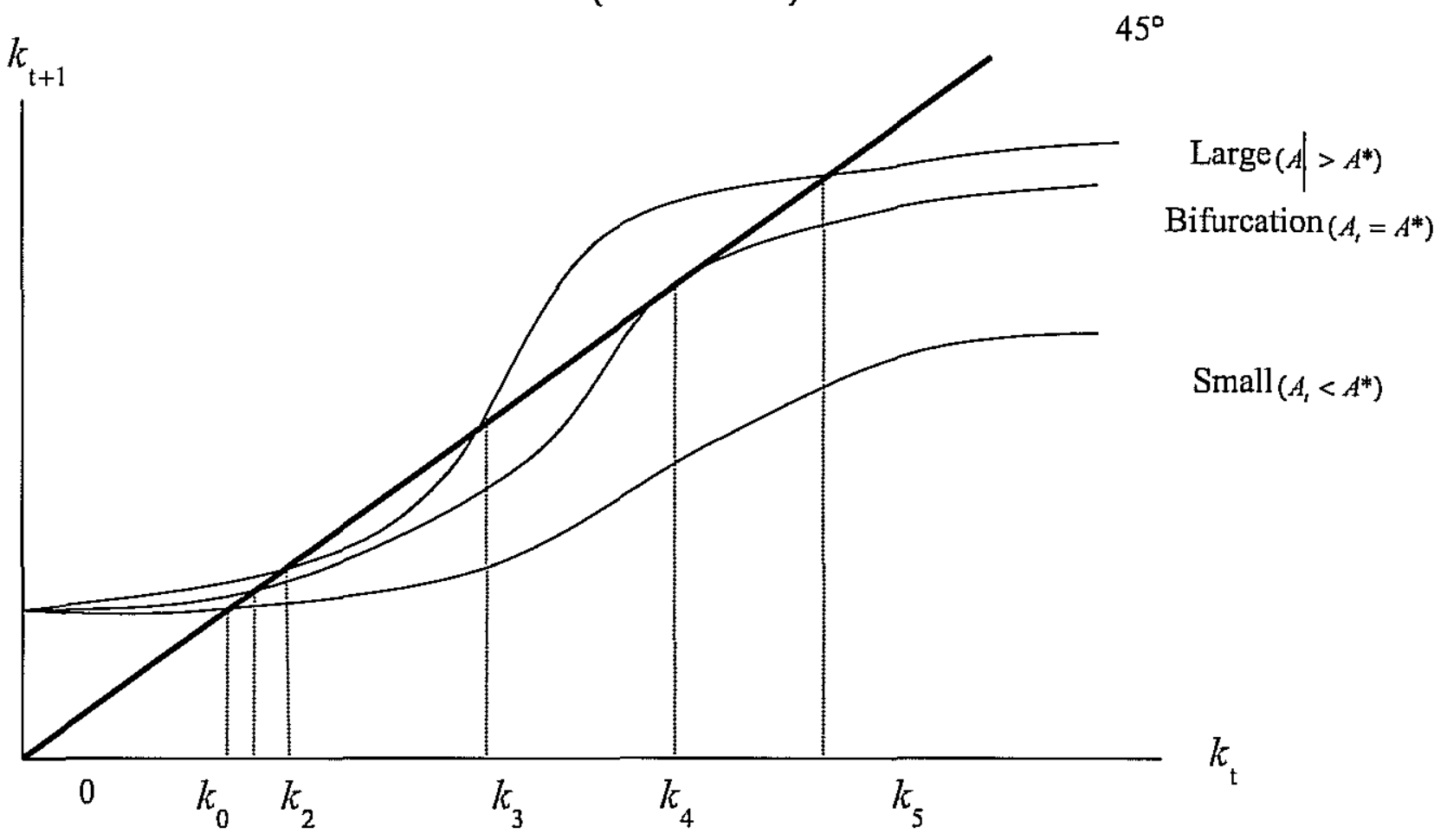


Figure 6

Phase Diagram for The

Transition Economies

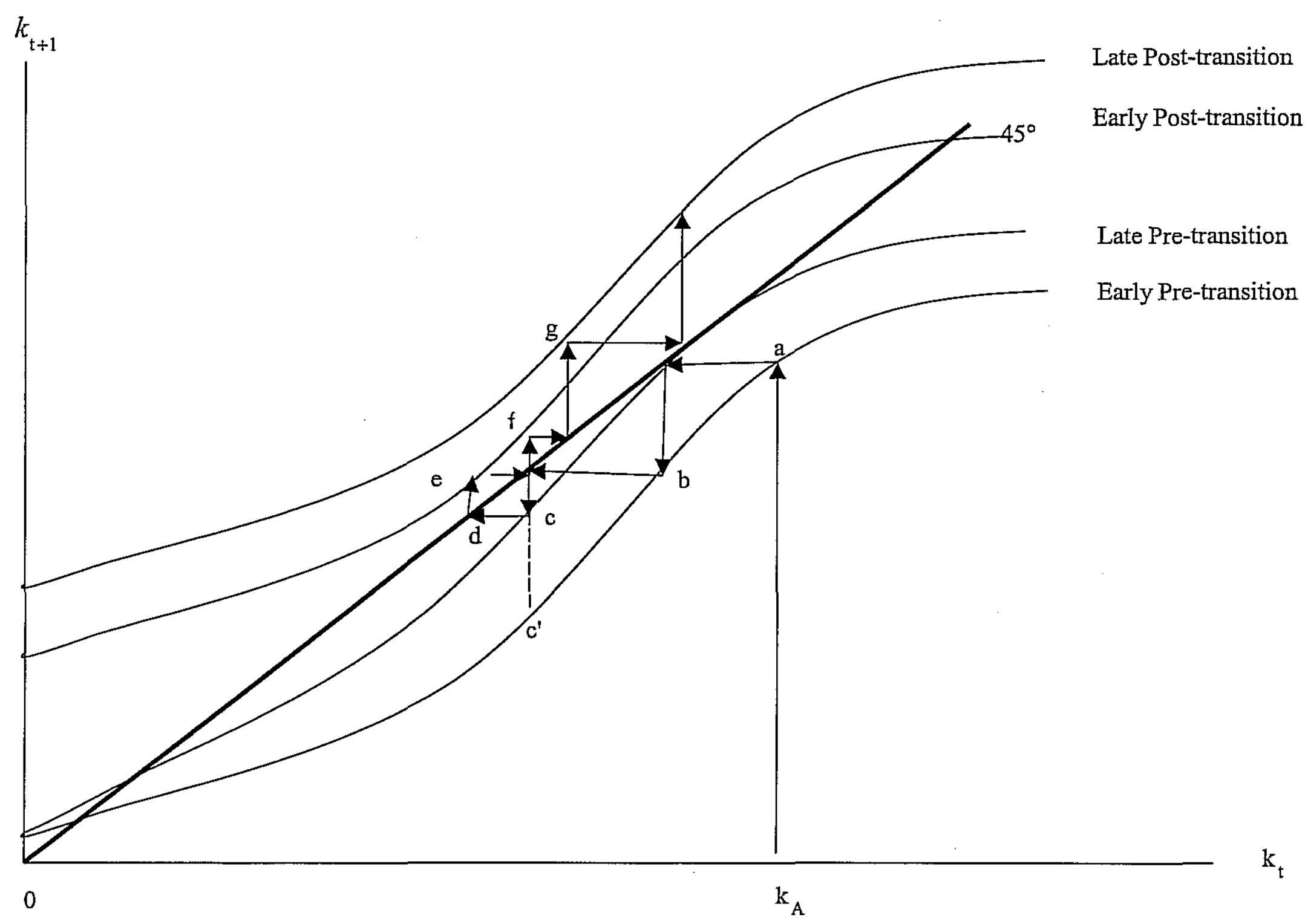




\section{DISCUSSION PAPERS \\ Department of Economics \\ The University of Western Australia}

Discussion Paper

02-15

02-14

$02-13$

02-12

$02-11$

02-10

02-09

02-08

02-07

02-06

02-05
Author

Yanrui Wu

Yanrui Wu

Don Stammer

Lee, $M$.

Tcha, $\mathrm{M}$.

Tcha, $\mathrm{M}$.

Kuriyama, T.
Title

Technical Efficiency and Its Determinants in Chinese Manufacturing Sector

Demand for Feedgrain in China: Implications for Foodgrain Consumption and Trade

The Shann Memorial Lecture

Change in the Australian Economy: What it Means for Australians... and... What it Means for Australian Economists

An analysis of Fiscal Policy and Economic Growth: the Case of Transition Economies

Welfare Effects of Protection and Economies of Scale - the Case of the Australian Automotive Industry

Clements, K. W. Three Facts About Marijuana Prices

Tcha, M.

Pershin, V.

Reconsidering Performance at the Summer Olympics and Revealed Comparative Advantage

Chiswick, B.R. Longitudinal Analysis of Immigrant Lee, Y.L. Occupational Mobility: A Test of the Immigrant Miller, P.W. Assimilation Hypothesis

Chiswick, B.R. Immigrants' Language Skills: The Australian Lee, Y.L. Miller, P.W. Experience

Chiswick, B.R. Family Matters: The role of the Family in Lee, Y.L. Miller, P.W.

Chiswick, B.R. Immigrants' Language Skills and Visa Category Lee, Y.L. Miller, P.W. 
Groenewold, N. The Efficiency of Federal Inter-Regional Hagger, A. Transfers Under a Regime of PoliticallyMadden, J.R. Maximizing Regional Governments

Groenewold, N. The Dynamic Interrelationships Between the Tang, S.H.K. Greater China Share Markets $\mathrm{Wu}, \mathrm{Y}$. 


